\section{Original Research}

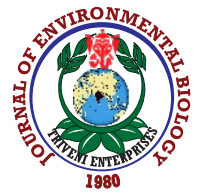

DOI : http://doi.org/10.22438/jeb/42/4(SI)/MRN-1532a
Journal website : www.jeb.co.in $\star$ E-mail : editor@jeb.co.in

Journal of Environmental Biology

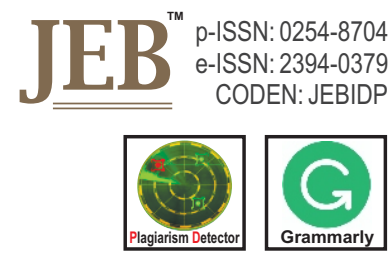

\title{
Modulations in carbon and nitrogen assimilation patterns in rice plants exposed to elevated atmospheric carbon dioxide concentrations
}

\author{
S.K. Rajkishore ${ }^{1 *}$, P. Doraisamy ${ }^{1}$, M. Maheswari', K.S. Subramanian², R. Prabhu ${ }^{3}$ and G. Vanitha ${ }^{4}$ \\ ${ }^{1}$ Department of Environmental Sciences, Tamil Nadu Agricultural University, Coimbatore - 641003 , India \\ ${ }^{2}$ Department of Nano Science \& Technology, Tamil Nadu Agricultural University, Coimbatore - 641003 , India \\ ${ }^{3}$ Department of Genetics and Plant Breeding, Tamil Nadu Agricultural University, Coimbatore - 641003 , India \\ ${ }^{4}$ Department of Physical Sciences and Information Technology, Tamil Nadu Agricultural University, Coimbatore - 641 003, India
}

*Corresponding Author Email : rajkishoresk@gmail.com

\section{Abstract}

Aim: To study the influence of elevated atmospheric $\mathrm{CO}_{2}$ concentrations on the carbon and nitrogen assimilation patterns in rice plants.

Methodology: Rice (Oryza sativa) plants were placed in Open Top Chambers (OTCs) and exposed to elevated levels of $\mathrm{CO}_{2}$. The treatments consisted of three levels of $\mathrm{CO}_{2}\left(398,550\right.$ and $\left.750 \mu \mathrm{mol} \mathrm{mol}{ }^{-1}\right)$ and three levels of nitrogen $\left(0,150\right.$ and $\left.200 \mathrm{~kg} \mathrm{ha}^{-1}\right)$ and replicated five times in completely randomized design.

Results: Leaf nitrogen was significantly reduced by $10.6 \%$ and $6.5 \%$ during later stages in rice plants exposed to $\mathrm{CO}_{2} @ 750 \mu \mathrm{mol} \mathrm{mol}^{-1}$ and $550 \mu \mathrm{mol} \mathrm{mol}{ }^{-1}$, respectively over the ambient $\mathrm{CO}_{2}$. Rice plants under elevated $\mathrm{CO}_{2}$ did not exhibit any variations in Nitrate Reductase activity in leaves in comparison to ambient $\mathrm{CO}_{2}$ at tillering stage. Interestingly, NRase activity in leaves decreased at flowering stage whereas NRase activity in roots increased at same stage. The highest mean nitrogen values $\left(0.58,0.89\right.$ and $1.35 \%$ ) were observed in $\mathrm{C}_{\text {amb }}$ (ambient $\mathrm{CO}_{2}$ concentration) and the lowest values $(0.51,0.80$ and $1.27 \%)$ in $\mathrm{C}_{750}$ in roots, straw and grains, respectively. Elevated $\mathrm{CO}_{2} @ 750 \mu \mathrm{mol} \mathrm{mol}^{-1}$ significantly increased the above ground biomass (straw and grain) by 15.6 and $40.1 \%$, respectively, over the ambient $\mathrm{CO}_{2}$ of $398 \mathrm{umol} \mathrm{mol}^{-1}$.

Interpretation: Elevated $\mathrm{CO}_{2}$ enhanced the grain productivity but affected the quality of rice grains. Thus, excessive nitrogen fertilization above the current recommendation is necessary for future high $\mathrm{CO}_{2}$ environments.

Key words: Atmospheric $\mathrm{CO}_{2}$ Open Top Chamber, Rice

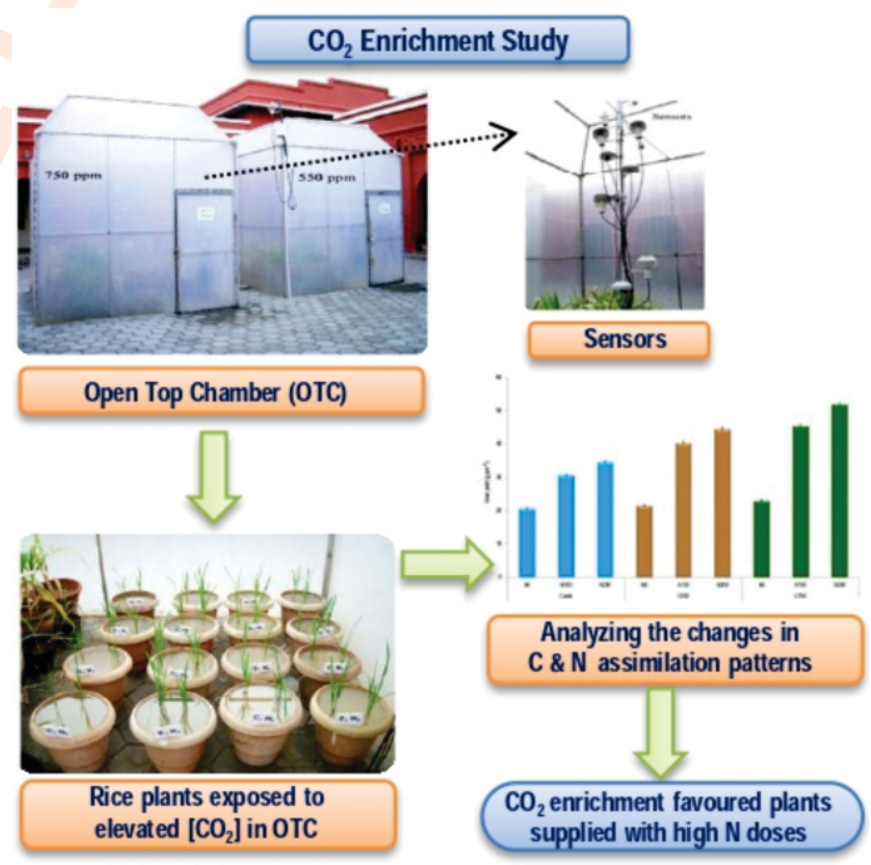

How to cite : Rajkishore S.K., P. Doraisamy, M. Maheswari, K.S. Subramanian, R. Prabhu and G. Vanitha, Modulations in carbon and nitrogen assimilation patterns in rice plants exposed to elevated atmospheric carbon dioxide concentrations. J. Environ. Biol, 42, 1114-1125 (2021). 


\section{Introduction}

Alarming increase in carbon emissions is a serious matter of concern for people on earth in general and environmental scientists in particular. Global warming is closely related to the rise in Green House Gas emissions such as $\mathrm{CO}_{2}, \mathrm{CH}_{4}$ and $\mathrm{N}_{2} \mathrm{O}$ that contribute to the tune of 60,20 and $6 \%$ (IPCC, 2013). Despite several gases responsible for enhanced greenhouse effect, $\mathrm{CO}_{2}$ emission is considered as a 'kingpin'. It has been observed that the atmospheric $\mathrm{CO}_{2}$ concentration was $280 \mathrm{ppm}$ in 1850 (Etheridge et al., 1996) and increased to 411 ppm in the year 2019 (NOAA, 2019) that commensurate with mean temperature rise of $1.0^{\circ} \mathrm{C}$ during the $20^{\text {th }}$ century (IPCC, 2018). This trend continues to increase at an alarming rate which may result in serious consequences. Agriculture is critical for human survival and its importance for the environment and climate is less recognized. The global concern of $21^{\text {st }}$ century is food security to meet the demand of burgeoning population within the degrading natural resources (Arora et al., 2011). Farming is further stressed by the impact of climate change. Rice (Oryza sativa) crop was selected because it is a staple food for more than half of the world's population (Bargali et al., 2007 \& 2009) and grown on161 million ha with an average annual production of 6787 million tones (Vibhuti et al., 2015 a, b; Khatri et al., 2020; Negi et al., 2020). Rice continues to be a major food crop and serves as a staple diet for more than 700 million people in India (FAO, 2011). Despite the fact that the crop has been researched in various spheres focusing on productivity, the average per hectare yield hardly exceeds 5 tonnes. Moreover, the Carbon sequestration pattern of rice eco-system is likely to be altered or modified under the various scenarios of climate change. Such events are often predicted by enriching the atmosphere with $\mathrm{CO}_{2}$ under Open Top Chamber conditions. It has also been estimated that the year 2050 and 2100 are the critical time frame for evaluation where atmospheric $\mathrm{CO}_{2}$ concentrations is likely to exceed 550 and 750 ppm. It is well known that rice plant possesses $C_{3}$ photosynthetic pathway and is less efficient due to the fact that the assimilated carbon gets decarboxylated under the current atmospheric $\mathrm{CO}_{2}$ concentrations. Thus, the elevated $\mathrm{CO}_{2}$ is considered as carbon fertilization to promote photosynthetic activities and improve the productivity of crops. However, the other factors such as nitrogen fertilization, temperature and water may cause inhibitory or supplementary effects on carbon assimilation in rice plants. It is well documented beyond doubt that carbon and nitrogen cycles co-exist and complement each other (Reich et al., 2006). Any alterations in one factor will up-regulate or down-regulate the biochemical pathways, but the mechanisms underlying such processes are poorly understood and need systematic investigations. Hence, this research was carried out to understand the influence of elevated atmospheric $\mathrm{CO}_{2}$ concentrations on the carbon and nitrogen assimilation patterns in rice plants.

\section{Materials and Methods}

Open Top Chambers: The effect of elevated levels of $\mathrm{CO}_{2}$ viz., $550 \mu \mathrm{mol} \mathrm{mol}^{-1} \mathrm{CO}_{2}$ and $750 \mu \mathrm{mol} \mathrm{mol}^{-1} \mathrm{CO}_{2}$ on rice crops were investigated employing Open Top Chambers installed at the Department of Soil Science and Agricultural Chemistry, TNAU, Coimbatore. The equipment for monitoring and controlling the $\mathrm{CO}_{2}$ in OTCs was fully automated and desired $\mathrm{CO}_{2}$ concentrations (550 ppm and $750 \mathrm{ppm}$ ) were maintained throughout the experimental period. The entire system was linked to data logger and computer system with UPS for uninterrupted data recording and storing.

Microcosm study: Seven kilograms of wetland soil (air dried, $2 \mathrm{~mm}$ ) was weighed and transferred into a syntex pot (top diameter $18 \mathrm{~cm}$, bottom diameter $16 \mathrm{~cm}$, height $20 \mathrm{~cm}$ and the holes at the bottom were sealed for the purpose of water stagnation). FYM at the recommended dose of $12.5 \mathrm{tha}^{-1}(41.6 \mathrm{~g}$ pot $\left.^{-1}\right)$ and NPK at 150:50:60 $\mathrm{kg} \mathrm{ha}^{-1}\left(500,166.6,200 \mathrm{mg} \mathrm{NPK} \mathrm{pot}^{-1}\right)$ were applied in the form of urea, single super phosphate and muriate of potash, respectively. Zinc sulphate @ $25 \mathrm{~kg} \mathrm{ha}^{-1}$ (83.3 $\mathrm{mg} \mathrm{pot}^{-1}$ ) was applied and was thoroughly mixed with the soil. Nitrogen and phosphorus were applied in four splits and $P$ was applied basally before transplanting. Rice crop was treated with three different levels of Nitrogen viz., 0, 150, $200 \mathrm{~kg} \mathrm{~N} \mathrm{ha}^{-1}$ and the $\mathrm{N}$ was applied in four splits on soil weight basis. Nursery was raised in the wetland farm and 14 days old paddy (ADT 45) seedlings were transplanted into the pots. After establishment, two healthy seedlings were allowed to grow in each pot. Twenty five-day old rice crop was subjected to different $\mathrm{CO}_{2}$ atmospheric conditions $\left(398,550\right.$ and $750 \mathrm{ppm} \mu \mathrm{mol} \mathrm{mol}{ }^{-1} \mathrm{CO}_{2}$ ) and rice crop was continuously kept under these conditions until harvest. The pots were maintained under flooded conditions (cyclic submergence) throughout the crop period.

\section{Treatments}

\section{Design: FCRD}

Replications: Five

\section{Factor 1:}

$$
\begin{aligned}
& \mathrm{C}_{\mathrm{amb}}-\text { Ambient } \mathrm{CO}_{2} \text { concentration }\left(398 \mu \mathrm{mol} \mathrm{mol} \mathrm{CO}^{-1} \mathrm{Co}_{2}\right) \\
& \mathrm{C}_{550}-550 \mu \mathrm{mol} \mathrm{mol}{ }^{-1} \mathrm{CO}_{2} \\
& \mathrm{C}_{750}-750 \mu \mathrm{mol} \mathrm{mol}{ }^{-1} \mathrm{Co}_{2}
\end{aligned}
$$

\section{Factor 2:}

$$
\begin{aligned}
& N_{0}-0 \mathrm{~kg} \mathrm{~N} \mathrm{ha}^{-1} \\
& \mathrm{~N}_{100}-150 \mathrm{~kg} \mathrm{~N} \mathrm{ha}^{-1} \\
& \mathrm{~N}_{200}-200 \mathrm{~kg} \mathrm{~N} \mathrm{ha}^{-1}
\end{aligned}
$$

Initial soil characteristics: The soil used in the pot experiment was sandy clay and belonged to Noyyal series, classified taxonomically as Typic Ustochrept according to USDA classification. The results revealed that the soil was slightly alkaline in nature $(\mathrm{pH}=8.21)$ with low soluble salts $(\mathrm{EC}=0.35)$. The soil was high in organic carbon content $\left(6.78 \mathrm{~g} \mathrm{~kg}^{-1}\right)$, low in available nitrogen (110.3 $\mathrm{mg} \mathrm{kg}^{-1}$ ), medium in available phosphorus and potassium (6.8 $\mathrm{mg} \mathrm{kg}^{-1}$ and $\left.118.0 \mathrm{mg} \mathrm{kg}^{-1}\right)$, respectively. 
Chlorophyll content: Fresh leaf samples $(250 \mathrm{mg})$ were macerated in a pestle and mortar with $10 \mathrm{ml}$ of $80 \%$ acetone and centrifuged at $5000 \mathrm{rpm}$ for $10 \mathrm{~min}$. The supernatant was collected and the volume was made up to $25 \mathrm{ml}$ using $80 \%$ acetone and the chlorophyll content was obtained by measuring the $\mathrm{OD}$ at 645,663 and $652 \mathrm{~nm}$ on a spectrophotometer (Elico BL 198) and expressed in $\mathrm{mg} \mathrm{g}^{-1}$ fresh weight (Bruinsma, 1963).

Soluble proteins: Soluble proteins in rice leaves were determined by the Folin phenol method (Lowry et al., 1951) using bovine serum albumin (BSA) as a standard. The soluble protein content was expressed as $\mathrm{mg} \mathrm{g}^{-1}$.

Nitrate Reductase (Nrase): Nitrate reductase activity in leaves and roots were determined by adopting the method of Nicholas et al. (1976). The enzyme activity was expressed as $\mu$ mole $\mathrm{NO}_{2} \mathrm{hr}^{-1}$ $\mathrm{g}^{-1}$ fresh weight.

Glutamine Synthetase (GS): Glutamine synthetase activity in leaves and roots were determined by following method Sadasivam and Manickam (1991). GS activity was expressed as $\mu \mathrm{mol}$ y-glutamyl hydroxamate formed per min per gram of fresh weight.

Glutamate Synthase (GOGAT): Glutamate synthase activity in leaves and roots were assayed by a modified method of Matoh et al. (1980) as described by Suzuki and Gadal (1982). One unit of GOGAT enzyme activity was expressed as $1 \mu \mathrm{mol}$ of glutamate formed per min at $30^{\circ} \mathrm{C}$.

Glutamate Dehydrogenase (GDH): Glutamate dehydrogenase activity in leaves and roots were assayes by the method of Sadasivam and Manickam (1991). The change in the absorbance at $340 \mathrm{~nm}$ was recorded and the GDH activity was expressed as $\mu$ mol NADH oxidized $\min ^{-1} g^{-1}$ fresh weight.

Carbon content: The carbon content of straw, root and grains were measured by using high temperature TOC analyser (Elementer, Model: Liqui TOC II). Temperature was maintained at $850^{\circ} \mathrm{C}$ pressure of 0.9 to 1 bar. Pure oxygen was used as a synthetic gas.

Nitrogen content: The nitrogen content of straw, root and grains were determined by method of Humphries (1956). About $10 \mathrm{~mL}$ of the diacid $\left(\mathrm{H}_{2} \mathrm{SO}_{4}\right.$ and $\mathrm{HClO}_{4}$ in 5:2) digest was taken and transferred to microkjeldahl to distill the Ammonia. $2 \%$ boric acid with 2-3 drops of double indicator was used to collect evolved Ammonia and titrated against $0.02 \mathrm{~N}$ sulphuric acid. Blanks were maintained without adding sample.

Statistical analysis: The data on various parameters studied during the course of investigation were statistically analyzed as suggested by Gomez and Gomez (1984). Wherever the treatment differences were found significant, critical difference were worked out at $5 \%$ level of significance with mean separation by least significant difference and denoted by symbol ${ }^{*}\left({ }^{* \star}\right.$ for $1 \%$ ). Treatment differences that were not significant were denoted as 'NS'.

\section{Results and Discussion}

Physiological parameters such as total chlorophyll content, soluble protein and nitrogen assimilatory enzymes were estimated to gain insights on the response of rice plants under elevated $\mathrm{CO}_{2}$ with varying levels of nitrogen. The total chlorophyll content was significantly higher under elevated $\mathrm{CO}_{2}$ at the tillering stage, but the trend was reversed with the advancement of crop growth (Fig.1). The increased chlorophyll contents at the tillering stage under elevated $\mathrm{CO}_{2}$ is due to the fact that the short-term $\mathrm{CO}_{2}$ enrichment stimulates the rate of photosynthesis (Makino and Mae, 1999) and simultaneously increases the nitrogen uptake (Seneweera et al., 2005). This statement is also supported by our results on leaf nitrogen content (Fig.2) which had positive correlation with chlorophyll content because during this period plant needs more nutrients for its physical growth. On the other hand, the decline in leaf chlorophyll in response to $\mathrm{CO}_{2}$ enrichment cannot be solely explained by a dilution effect (Epron et al., 1996). Such a decrease in leaf chlorophyll has frequently been reported in young plants in response to elevated $\mathrm{CO}_{2}$ (Wullschleger et al., 1992) and may have some physiological significance. Decrease in chlorophyll content at the later stages under atmospheric $\mathrm{CO}_{2}$ enrichment suggests that elevated $\mathrm{CO}_{2}$ causes less Nitrogen to be invested in the light reactions of photosynthesis (Epron et al., 1996). Further, many studies suggest that decreases in leaf Nitrogen and chlorophyll content under elevated $\mathrm{CO}_{2}$ levels are often associated with reduced responses of leaf photosynthesis (Kim and You, 2010). In general, a decreasing trend in the chlorophyll contents was observed with the progression of crop growth irrespective of $\mathrm{CO}_{2}$. This observation is line with Imai et al. (2008) who reported that the chlorophyll contents increased in young expanding leaves and decreased substantially during senescence. Nitrogen fertilization was found to increase the chlorophyll content irrespective of $\mathrm{CO}_{2}$ or stages of observation. In any species, a large proportion of nitrogen is allocated to leaves throughout their life cycle. For instance, in rice, at early panicle initiation stage about $65-70 \%$ of the total nitrogen in the shoot is invested in the leaf blade and 20 to $30 \%$ in the leaf sheath (Seneweera et al., 2005). A major proportion of leaf $\mathrm{N}(\sim 80 \%)$ is allocated to chloroplasts and most of the nitrogen in the chloroplast are invested in photosynthetic protein, including large amount in Rubisco and Thylakoid Protein (Evans, 1989).

In this investigation, the soluble proteins were estimated (Table 1) as it accounts for more than $50 \%$ of rubisco content (Suzuki et al., 2001) besides it is the reliable index for assessing the photosynthetic efficiency (Jensen and Bahr, 1977). The soluble proteins increased in the rice plants exposed to elevated $\mathrm{CO}_{2}$ at the tillering stage, but the trend of response was reversed with the advancement of crop growth. Since soluble proteins are an indirect measure of rubisco content, this can be well explained with the literatures dealing rubisco content under elevated $\mathrm{CO}_{2}$. It has been demonstrated that under elevated $\mathrm{CO}_{2}$, rubisco content in the leaf varies during development (Seneweera et al., 2002) and it was found to be significantly reduced at the reproductive 


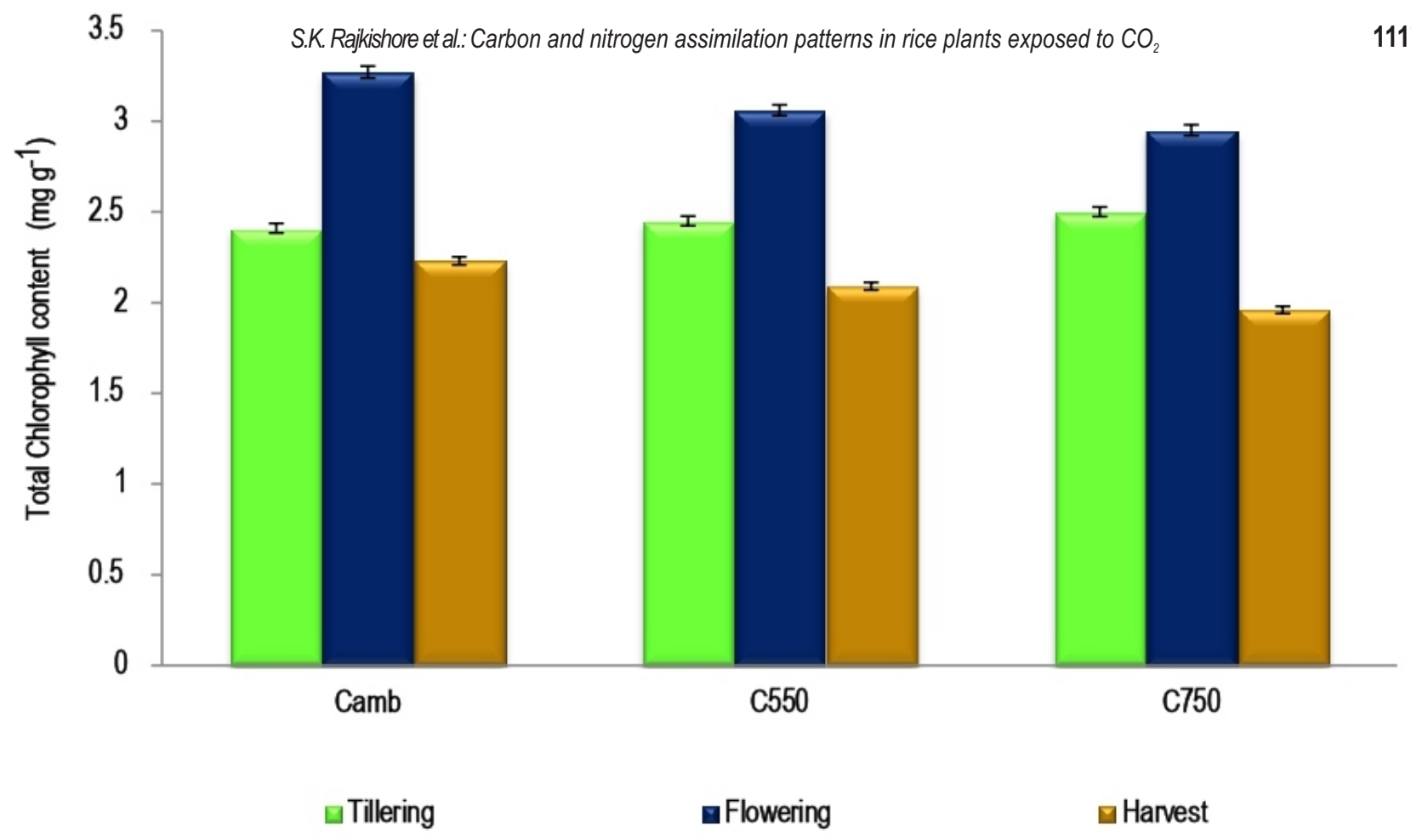

Fig. 1: Effect of elevated $\mathrm{CO}_{2}$ on total chlorophyll content at various stages of rice growth.

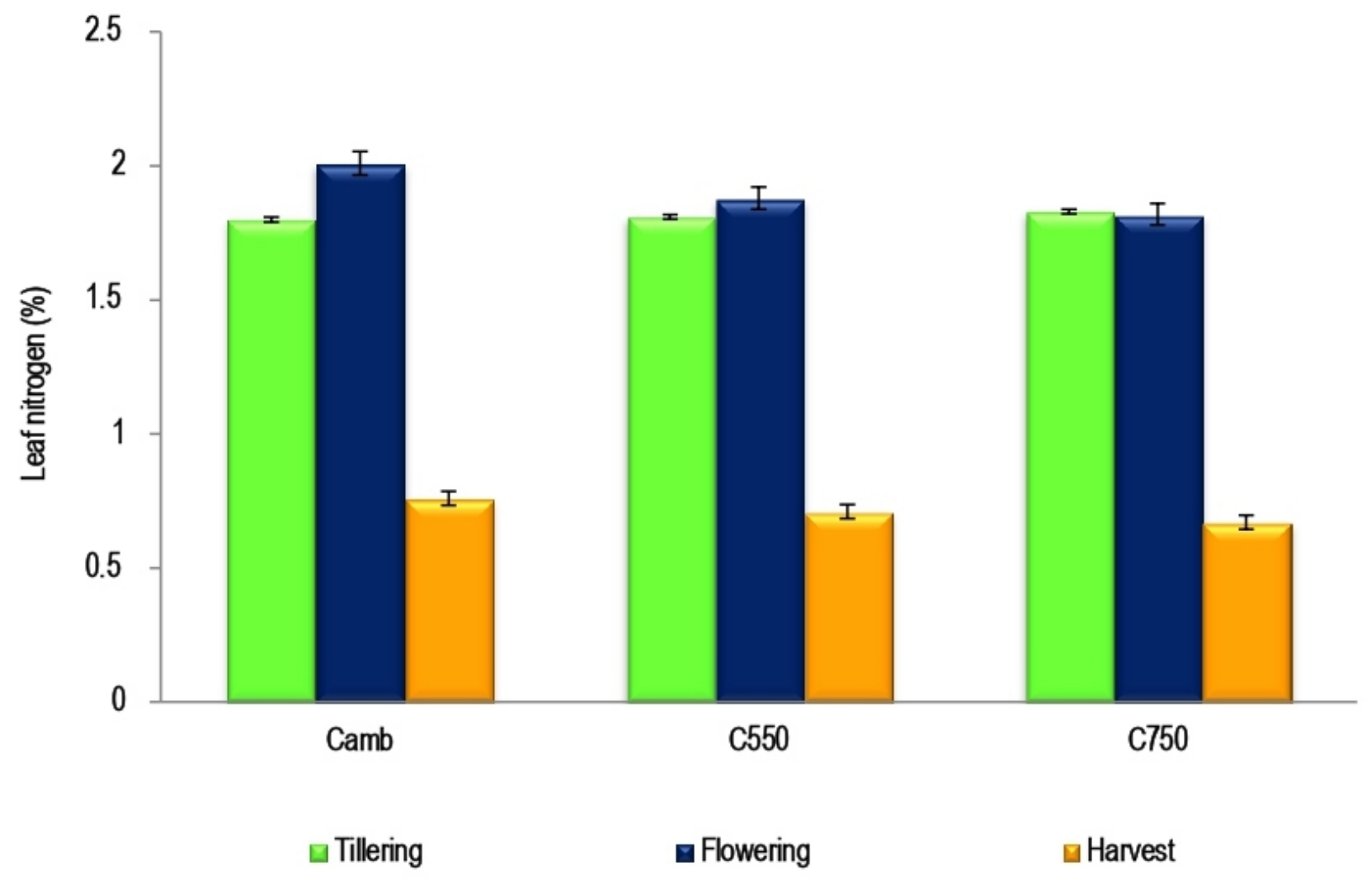

Fig. 2: Effect of elevated $\mathrm{CO}_{2}$ on leaf nitrogen content at various stages of rice growth. 
stage. These changes in rubisco content are related to modulation in $\mathrm{C}$ and $\mathrm{N}$ balance due to changes in source and sink activity during development but the underlying mechanism is not clearly understood (Seneweera et al., 2005). Another possibility is that plants reduced their $\mathrm{N}$ allocation for photosynthetic Proteins, making Nitrogen more freely available for rapid sink development. In the present study, even though the soluble proteins, an indirect measure of rubisco was found to be reduced at later stages under elevated $\mathrm{CO}_{2}$, the biomass harvested is significantly higher under the elevated $\mathrm{CO}_{2}$. This is attributed to the fact that at elevated $\mathrm{CO}_{2}$, photosynthesis is not limited by rubisco content whereas electron transport capacity (Farquhar et al., 1980) or availability of $P_{i}$ in the chloroplast to synthesize ATP limits the photosynthesis (Sharkey, 1985). This data suggest that rubisco content is not necessarily important to maintain high photosynthetic rates at elevated $\mathrm{CO}_{2}$ and other regulatory mechanisms within the photosynthetic machinery may exist for downregulation of photosynthesis. Moreover, reports indicate that the decrease in rubisco content is not accompanied by a decline in $\mathrm{CO}_{2}$ assimilation rates because the activation state of rubisco increased (Cheng and Fuchigami, 2000).

Our study indicated that on an average the leaf Nitrogen was significantly reduced by $10.6 \%$ and $6.5 \%$ during the later stages in the rice plants exposed to $\mathrm{CO}_{2} @ 750 \mathrm{umol} \mathrm{mol}^{-1}$ and $550 \mu \mathrm{mol} \mathrm{mol}{ }^{-1}$, respectively over the ambient $\mathrm{CO}_{2}$. These results are in agreement with Anten et al. (2003) who reported that the rice grown at elevated $\mathrm{CO}_{2}\left(200 \mu \mathrm{mol} \mathrm{mol}{ }^{-1}\right.$ above ambient) registered reduced leaf nitrogen. This decrease was found only after panicle initiation and the reason for these differences could be due to an increase in nitrogen demand for larger panicles in plants grown at elevated $\mathrm{CO}_{2}$ (Seneweera et al., 2002). One of the common explanation for the reduction in leaf nitrogen concentration in plants grown at elevated $\mathrm{CO}_{2}$ is the dilution of nitrogen due to extra Carbohydrate accumulation (Conroy, 1992). But several publications (Nakano et al. (1997); Makino and Mae, 1999) disagrees the 'dilution effect' concept and instead it is explained that the decrease in leaf nitrogen content is the result of a change in nitrogen allocation of the whole plant. According to Makino and Mae (1999), the nitrogen investment in the leaf blades decreases under $\mathrm{CO}_{2}$ enrichment irrespective of nitrogen treatments, whereas the plants enhance the allocation of $\mathrm{N}$ to the leaf sheaths and roots. This means that during long-term growth under conditions of elevated $\mathrm{CO}_{2}$, plants reallocate nitrogen away from leaf blades to leaf sheaths and roots. In addition, since nitrogen invested into leaf blades is the most important source for photosynthesis in the whole plant, these results also indicate that plants regulate photosynthesis by changing nitrogen allocation at the whole plant level.

To further understand the underlying reasons for reduced plant tissue Nitrogen under elevated $\mathrm{CO}_{2}$, the nitrogen assimilatory enzymes viz., Nitrate Reductase, Glutamine Synthetase, Glutamate Synthase, Glutamate Dehydrogenase in the rice leaves and roots were estimated (Table 2 and 3 ). The ability of plants to acquire and assimilate nitrogen is an
Table 1: Effect of elevated $\mathrm{CO}_{2}$ and nitrogen levels on soluble protein contents

\begin{tabular}{|c|c|c|c|c|c|c|c|}
\hline \multirow{2}{*}{\multicolumn{2}{|c|}{ Treatments }} & \multicolumn{6}{|c|}{ Soluble protein content $\left(\mathrm{mg} \mathrm{g}^{-1}\right)$} \\
\hline & & \multicolumn{2}{|c|}{ Tillering } & \multicolumn{2}{|c|}{ Flowering } & \multicolumn{2}{|c|}{ Maturity } \\
\hline \multirow[t]{3}{*}{$C_{a m b}$} & $\mathrm{~N}_{0}$ & 7.5 & & 13.6 & & 4.2 & \\
\hline & $\mathbf{N}_{150}$ & 8.4 & & 17.9 & & 6.1 & \\
\hline & $\mathbf{N}_{200}$ & 9.0 & & 18.7 & & 6.5 & \\
\hline \multirow{3}{*}{$\mathrm{C}_{550}$} & $\mathbf{N}_{0}$ & 7.0 & & 13.3 & & 3.8 & \\
\hline & $\mathbf{N}_{150}$ & 8.8 & & 16.5 & & 5.7 & \\
\hline & $\mathbf{N}_{200}$ & 9.2 & & 17.6 & & 6.0 & \\
\hline \multirow[t]{4}{*}{$C_{750}$} & $\mathrm{~N}_{0}$ & 6.7 & & 12.8 & & 3.4 & \\
\hline & $\mathbf{N}_{150}$ & 9.1 & & 16.0 & & 5.5 & \\
\hline & $\mathbf{N}_{200}$ & 9.4 & & 17.0 & & 5.8 & \\
\hline & & SEd & $C D$ & SEd & $C D$ & SEd & $C D$ \\
\hline \multirow{2}{*}{\multicolumn{2}{|c|}{$\begin{array}{l}\mathrm{C} \\
\mathrm{N}\end{array}$}} & 0.069 & NS & 0.131 & $0.267^{\star *}$ & 0.043 & $0.087^{* *}$ \\
\hline \multirow{2}{*}{\multicolumn{2}{|c|}{$\begin{array}{l}N \\
C \times N\end{array}$}} & 0.069 & $0.139^{\star *}$ & 0.131 & $0.267^{* *}$ & 0.043 & $0.087^{* *}$ \\
\hline & & 0.119 & $0.242^{* *}$ & 0.228 & NS & 0.075 & NS \\
\hline
\end{tabular}

$\mathrm{CO}_{2}$ levels : $\mathrm{C}_{\mathrm{amb}}-398 \mu \mathrm{mol} \mathrm{mol}{ }^{-1} \mathrm{CO}_{2} ; \mathrm{C}_{550}-550 \mu \mathrm{mol} \mathrm{mol}{ }^{-1} \mathrm{CO}_{2} ; \mathrm{C}_{2}$ $-750 \mu \mathrm{mol} \mathrm{mol}{ }^{-1} \mathrm{CO}_{2}$; Nitrogen levels: $\mathrm{N}_{0}-0 \mathrm{~kg} \mathrm{~N} \mathrm{ha}^{-1} ; \mathrm{N}_{150}-150 \mathrm{~kg}$ $\mathrm{N}$ ha ${ }^{-1} ; \mathrm{N}_{200}-200 \mathrm{~kg} \mathrm{~N} \mathrm{a}^{-1} ;{ }^{*} P \leq 0.05,{ }^{*} P \leq 0.01$, NS - Non significant

important determinant of plant response to elevated $\mathrm{CO}_{2}$ and of ecosystem carbon sequestration (Luo et al., 2004). In this study, the plants exposed to elevated $\mathrm{CO}_{2}$ did not exhibit any variations in the NRase activity in leaves in comparison to ambient $\mathrm{CO}_{2}$ at tillering stage. Interestingly, our data revealed that the NRase activity in leaves were decreased at flowering stage. This suggests that despite increased nitrogen uptake under elevated $\mathrm{CO}_{2}$, the reallocation of nitrogen away from leaf blades might have led to decreased NRase activity in leaves at later stages of crop growth. Plant nitrogen status is a function of both soil $\mathrm{N}$ availability and plant nitrogen uptake and assimilation capacity. As a rate-limiting step in Nitrate assimilation, the reduction of Nitrate is an important component of plant physiological response to elevated $\mathrm{CO}_{2}$ and terrestrial Carbon sequestration (Natali et al., 2009). Both $\mathrm{CO}_{2}$ and nitrogen enrichment had species specific impacts on NRase activity. Both above and belowground assimilation processes may be altered by increasing concentrations of atmospheric $\mathrm{CO}_{2}$ (Searles and Bloom, 2003). The other possible reason for the reduction in NRase activity in leaves is that foliar $\mathrm{NO}_{3}{ }^{-}$reduction may compete for reductant with Calvin cycle reactions when Carbon assimilation is increased under elevated $\mathrm{CO}_{2}$ (Bloom et al., 2002). Because of the potential competitive effect between $\mathrm{NO}_{3}{ }^{-}$and $\mathrm{CO}_{2}$ reduction, foliar NRase may decrease with $\mathrm{CO}_{2}$ enrichment. However, variations in response are widely reported and this may be attributed to soil nitrogen form and concentration (Yong et al., 2007), plant species/functional group (Cousins and Bloom, 2003) and altered diurnal rhythm of NRase activity (Geiger et al., 1998). 
Table 2: Effect of elevated $\mathrm{CO}_{2}$ and nitrogen levels on Nitrate reductase and Glutamine synthetase activity in leaves

\begin{tabular}{|c|c|c|c|c|c|c|c|c|c|c|c|c|c|}
\hline \multirow{2}{*}{\multicolumn{2}{|c|}{ Treatments }} & \multicolumn{6}{|c|}{$\begin{array}{c}\text { Nitrate reductase } \\
\left(\mu \text { moles } \mathrm{NO}_{2} \mathrm{~g}^{-1} \mathrm{hr}^{-1}\right)\end{array}$} & \multicolumn{6}{|c|}{$\begin{array}{c}\text { Glutamine synthetase } \\
\text { ( } \mu \text { mol glutamyl hydroxomate } \min ^{-1} \mathrm{~g}^{-1} \mathrm{f} \text {.wt) }\end{array}$} \\
\hline & & \multicolumn{2}{|c|}{ Tillering } & \multicolumn{2}{|c|}{ Flowering } & \multicolumn{2}{|c|}{ Maturity } & \multicolumn{2}{|c|}{ Tillering } & \multicolumn{2}{|c|}{ Flowering } & \multicolumn{2}{|c|}{ Maturity } \\
\hline & $\mathrm{N}_{0}$ & \multicolumn{2}{|c|}{0.58} & \multicolumn{2}{|c|}{0.78} & \multicolumn{2}{|c|}{0.27} & \multicolumn{2}{|c|}{1.46} & \multicolumn{2}{|c|}{1.81} & \multicolumn{2}{|c|}{0.50} \\
\hline \multirow[t]{3}{*}{$\mathrm{C}_{\mathrm{amb}}$} & $N_{150}$ & \multicolumn{2}{|c|}{0.66} & \multicolumn{2}{|c|}{1.01} & \multicolumn{2}{|c|}{0.39} & & 63 & \multicolumn{2}{|c|}{2.33} & \multicolumn{2}{|c|}{0.73} \\
\hline & $\mathrm{N}_{200}$ & \multicolumn{2}{|c|}{0.71} & \multicolumn{2}{|c|}{1.07} & \multicolumn{2}{|c|}{0.41} & & 77 & \multicolumn{2}{|c|}{2.48} & \multicolumn{2}{|c|}{0.78} \\
\hline & $\mathrm{N}_{0}$ & \multicolumn{2}{|c|}{0.55} & \multicolumn{2}{|c|}{0.75} & \multicolumn{2}{|c|}{0.24} & & 37 & \multicolumn{2}{|c|}{1.73} & \multicolumn{2}{|c|}{0.46} \\
\hline \multirow[t]{3}{*}{$\mathrm{C}_{550}$} & $\mathrm{~N}_{150}$ & \multicolumn{2}{|c|}{0.69} & \multicolumn{2}{|c|}{0.93} & \multicolumn{2}{|c|}{0.36} & & 72 & & 16 & & 69 \\
\hline & $\mathrm{N}_{200}$ & & & & 0 & & & & 79 & & 31 & & 73 \\
\hline & $\mathrm{N}_{0}$ & & & & 72 & & & & 31 & & 34 & & 41 \\
\hline $\mathrm{C}_{750}$ & $\mathrm{~N}_{150}$ & & & & 91 & & & & 78 & & 10 & & 66 \\
\hline & $\mathrm{N}_{200}$ & & & & 96 & & & & 35 & & 21 & & 70 \\
\hline & & SEd & $C D$ & SEd & $C D$ & SEd & $C D$ & SEd & $C D$ & SEd & $C D$ & SEd & $C D$ \\
\hline & C & 0.005 & NS & 0.007 & $0.014^{* *}$ & 0.003 & $0.006^{* *}$ & 0.013 & NS & 0.017 & $0.035^{\star *}$ & 0.005 & $0.011^{* *}$ \\
\hline & $\mathbf{N}$ & 0.005 & $0.010^{* *}$ & 0.007 & $0.014^{* *}$ & 0.003 & $0.006^{* *}$ & 0.013 & $0.027^{* *}$ & 0.017 & $0.035^{* *}$ & 0.005 & $0.011^{* *}$ \\
\hline & $x N$ & 0.009 & $0.019^{* *}$ & 0.012 & NS & 0.005 & NS & 0.023 & $0.047^{* *}$ & 0.029 & NS & 0.009 & NS \\
\hline
\end{tabular}

$\mathrm{CO}_{2}$ levels $\quad: \mathrm{C}_{\text {amb }}-398 \mu \mathrm{mol} \mathrm{mol}{ }^{-1} \mathrm{CO}_{2} ; \mathrm{C}_{550}-550 \mu \mathrm{mol} \mathrm{mol}^{-1} \mathrm{CO}_{2} ; \mathrm{C}_{2}-750 \mu \mathrm{mol} \mathrm{mol}^{-1} \mathrm{CO}_{2}$

Nitrogen levels: $N_{0}-0 \mathrm{~kg} \mathrm{~N}$ ha $^{-1} ; \mathrm{N}_{150}-150 \mathrm{~kg} \mathrm{~N} \mathrm{ha}^{-1} ; \mathrm{N}_{200}-200 \mathrm{~kg} \mathrm{~N} \mathrm{ha}^{-1} ;{ }^{*} P \leq 0.05,{ }^{* *} P \leq 0.01$, NS - Non significant

Table 3: Effect of elevated $\mathrm{CO}_{2}$ and nitrogen levels on Glutamate Synthase and Glutamate dehydrogenase activity in leaves

\begin{tabular}{|c|c|c|c|c|c|c|c|c|c|c|c|c|c|}
\hline \multirow{2}{*}{\multicolumn{2}{|c|}{ Treatments }} & \multicolumn{6}{|c|}{$\begin{array}{c}\text { Glutamate Synthase } \\
\text { ( } \mu \text { mol glutamate } \min ^{-1} \mathrm{~g}^{-1} \text { fresh tissue) }\end{array}$} & \multicolumn{6}{|c|}{$\begin{array}{c}\text { Glutamate dehydrogenase } \\
\left(\mu \text { mol NADH oxidized } \min ^{-1} g^{-1} \text { f.wt) }\right.\end{array}$} \\
\hline & & \multicolumn{2}{|c|}{ Tillering } & \multicolumn{2}{|c|}{ Flowering } & \multicolumn{2}{|c|}{ Maturity } & \multicolumn{2}{|c|}{ Tillering } & \multicolumn{2}{|c|}{ Flowering } & \multicolumn{2}{|c|}{ Maturity } \\
\hline \multirow{4}{*}{$\mathrm{C}_{\mathrm{amb}}$} & $\mathrm{N}_{0}$ & \multicolumn{2}{|c|}{2.33} & \multicolumn{2}{|c|}{2.77} & \multicolumn{2}{|c|}{0.89} & \multicolumn{2}{|c|}{0.69} & \multicolumn{2}{|c|}{1.03} & \multicolumn{2}{|c|}{0.35} \\
\hline & $\mathbf{N}_{150}$ & \multicolumn{2}{|c|}{2.62} & \multicolumn{2}{|c|}{3.56} & \multicolumn{2}{|c|}{1.27} & \multicolumn{2}{|c|}{0.94} & \multicolumn{2}{|c|}{1.33} & \multicolumn{2}{|c|}{0.51} \\
\hline & $\mathrm{N}_{200}$ & \multicolumn{2}{|c|}{2.75} & \multicolumn{2}{|c|}{3.79} & \multicolumn{2}{|c|}{1.39} & \multicolumn{2}{|c|}{0.97} & \multicolumn{2}{|c|}{1.41} & \multicolumn{2}{|c|}{0.55} \\
\hline & $\mathrm{N}_{0}$ & \multicolumn{2}{|c|}{2.19} & \multicolumn{2}{|c|}{2.65} & \multicolumn{2}{|c|}{0.78} & \multicolumn{2}{|c|}{0.66} & \multicolumn{2}{|c|}{0.99} & \multicolumn{2}{|c|}{0.32} \\
\hline \multirow[t]{3}{*}{$\mathrm{C}_{550}$} & $\mathbf{N}_{150}$ & & & & & & & & & & & & 48 \\
\hline & $\mathrm{N}_{200}$ & & & & & & 30 & & & & & & 51 \\
\hline & $\mathrm{N}_{0}$ & & & & & & 73 & & & & & & 29 \\
\hline $\mathrm{C}_{750}$ & $\mathbf{N}_{150}$ & & & & & & 16 & & & & & & 46 \\
\hline & $\mathbf{N}_{200}$ & & & & & & 26 & & & & & & 49 \\
\hline & & SEd & $C D$ & SEd & $C D$ & SEd & $C D$ & SEd & $C D$ & SEd & $C D$ & SEd & $C D$ \\
\hline & $c$ & 0.021 & NS & 0.026 & $0.053^{* *}$ & 0.009 & $0.019^{* *}$ & 0.007 & NS & 0.009 & $0.019^{* *}$ & 0.004 & $0.007^{* *}$ \\
\hline & N & 0.021 & $0.043^{\star *}$ & 0.026 & $0.053^{* *}$ & 0.009 & $0.019^{* *}$ & 0.007 & $0.014^{\star *}$ & 0.009 & $0.019^{* *}$ & 0.004 & $0.007^{\star *}$ \\
\hline & $x \mathrm{~N}$ & 0.037 & $0.075^{* *}$ & 0.045 & NS & 0.016 & NS & 0.012 & $0.025^{\star *}$ & 0.016 & NS & 0.006 & NS \\
\hline
\end{tabular}

$\mathrm{CO}_{2}$ levels $\quad: \mathrm{C}_{\text {amb }}-398 \mu \mathrm{mol} \mathrm{mol}{ }^{-1} \mathrm{CO}_{2} ; \mathrm{C}_{550}-550 \mu \mathrm{mol} \mathrm{mol}^{-1} \mathrm{CO}_{2} ; \mathrm{C}_{2}-750 \mu \mathrm{mol} \mathrm{mol}^{-1} \mathrm{CO}_{2}$

Nitrogen levels: $N_{0}-0 \mathrm{~kg} \mathrm{~N} \mathrm{ha}^{-1} ; \mathrm{N}_{150}-150 \mathrm{~kg} \mathrm{~N} \mathrm{ha}^{-1} ; \mathrm{N}_{200}-200 \mathrm{~kg} \mathrm{~N} \mathrm{ha}^{-1} ;{ }^{*} P \leq 0.05$, ${ }^{* *} P \leq 0.01$, NS - Non significant

Carbon metabolism is inextricably linked to Nitrogen metabolism and any change in Carbon abundance impacts on Nitrogen metabolism and vice versa (Lewis et al., 2000). There is clear evidence that more than $95 \%$ of the Ammonium available to higher plants is assimilated via the GS/GOGAT pathway (Lea and Miflin, 1974). In the present study, the trend of response for GS,
GOGAT in rice leaves were similar to the NRase activity. The GS and GOGAT activities of leaves have shown to be lower under elevated $\mathrm{CO}_{2}$ indicating the process of remobilization of metabolites towards reproductive organs which in turn support grain growth. Moreover, the glutamate is the precursor for chlorophyll synthesis in leaves (Yaronskaya et al., 2006) and 


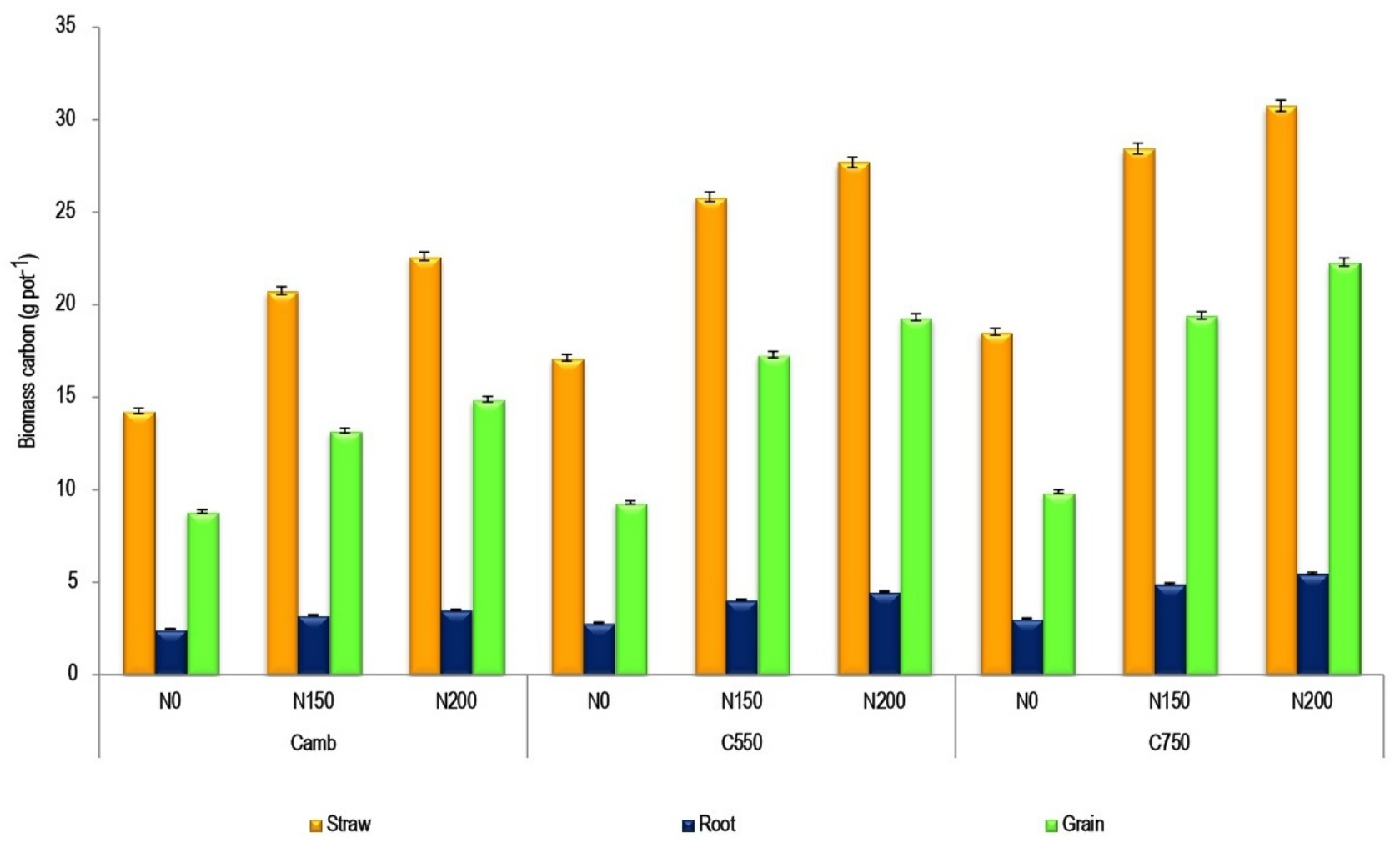

Fig. 3: Effect of elevated $\mathrm{CO}_{2}$ and different levels of nitrogen on rice biomass carbon.

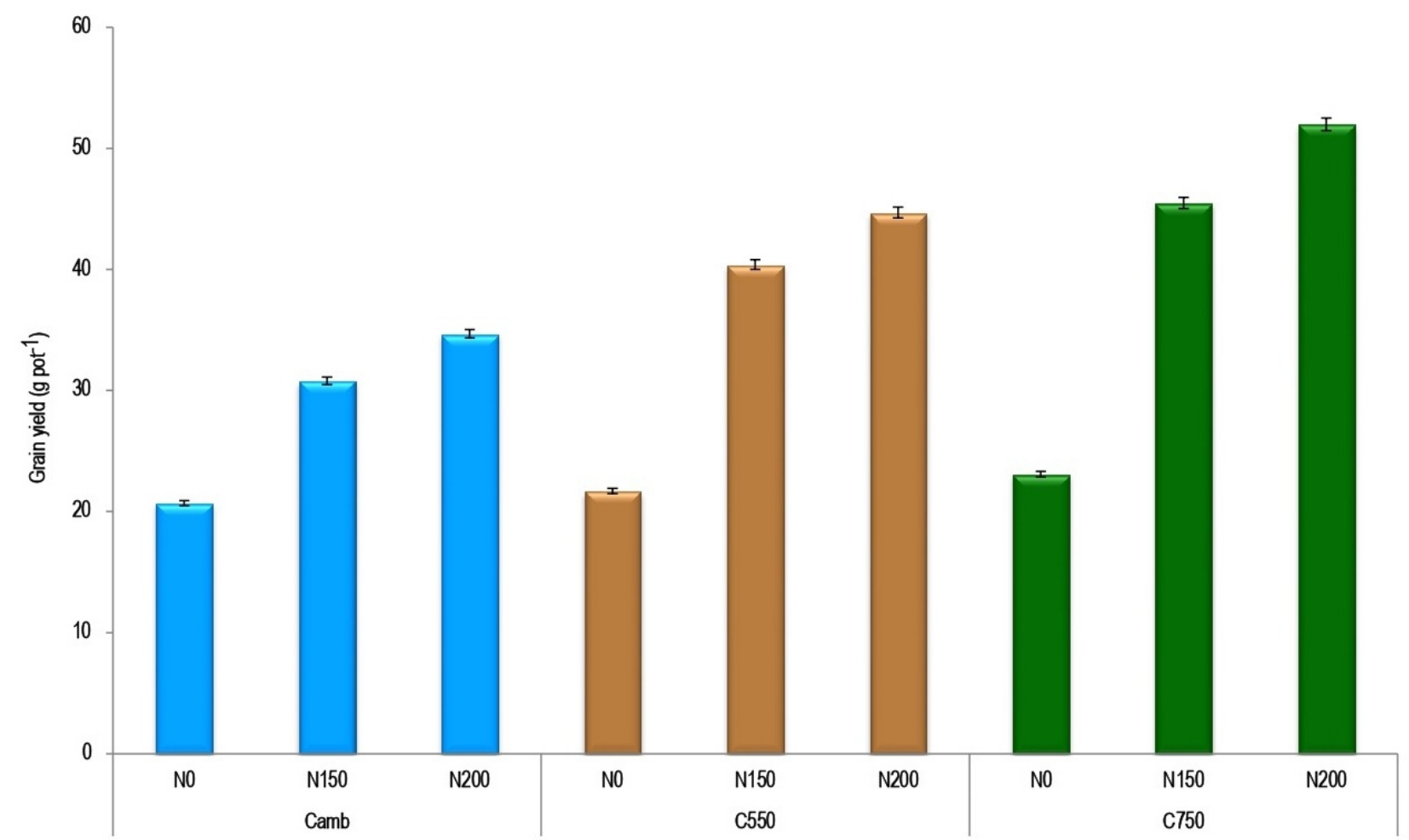

Fig. 4: Effect of elevated $\mathrm{CO}_{2}$ on different levels of nitrogen on rice grain yield. 
Table 4: Effect of elevated $\mathrm{CO}_{2}$ and nitrogen levels on yield

\begin{tabular}{|c|c|c|c|c|c|c|c|c|c|}
\hline \multicolumn{2}{|c|}{ Treatments } & \multicolumn{2}{|c|}{$\begin{array}{c}\text { Grain yield } \\
\text { (g per pot) }\end{array}$} & \multicolumn{2}{|c|}{$\begin{array}{c}\text { Straw yield } \\
\text { (g per pot) }\end{array}$} & \multicolumn{2}{|c|}{$\begin{array}{c}\text { Root yield } \\
\left(\mathrm{g} \mathrm{pot}^{-1}\right)\end{array}$} & \multicolumn{2}{|c|}{ Root : Shoot ratio } \\
\hline & $\mathrm{N}_{0}$ & \multicolumn{2}{|c|}{20.7} & \multicolumn{2}{|c|}{40.5} & \multicolumn{2}{|c|}{5.9} & \multicolumn{2}{|c|}{0.146} \\
\hline \multirow[t]{3}{*}{$C_{a m b}$} & $\mathrm{~N}_{150}$ & \multicolumn{2}{|c|}{30.8} & \multicolumn{2}{|c|}{59.1} & \multicolumn{2}{|c|}{7.7} & \multicolumn{2}{|c|}{0.130} \\
\hline & $\mathrm{N}_{200}$ & \multicolumn{2}{|c|}{34.7} & \multicolumn{2}{|c|}{64.3} & \multicolumn{2}{|c|}{8.4} & \multicolumn{2}{|c|}{0.131} \\
\hline & $\mathrm{N}_{0}$ & \multicolumn{2}{|c|}{21.7} & \multicolumn{2}{|c|}{43.5} & \multicolumn{2}{|c|}{7.3} & \multicolumn{2}{|c|}{0.168} \\
\hline \multirow[t]{3}{*}{$\mathrm{C}_{550}$} & $\mathrm{~N}_{150}$ & \multicolumn{2}{|c|}{40.4} & \multicolumn{2}{|c|}{65.4} & \multicolumn{2}{|c|}{10.5} & \multicolumn{2}{|c|}{0.161} \\
\hline & $\mathrm{N}_{200}$ & \multicolumn{2}{|c|}{44.7} & \multicolumn{2}{|c|}{70.1} & \multicolumn{2}{|c|}{11.6} & \multicolumn{2}{|c|}{0.165} \\
\hline & $\mathrm{N}_{0}$ & & & \multicolumn{2}{|c|}{45.2} & \multicolumn{2}{|c|}{7.7} & \multicolumn{2}{|c|}{0.170} \\
\hline \multirow[t]{6}{*}{$C_{750}$} & $\mathrm{~N}_{150}$ & \multicolumn{2}{|c|}{$\begin{array}{l}2.1 \\
45.5\end{array}$} & & & & & & \\
\hline & $\mathrm{N}_{200}$ & & & & & & & & \\
\hline & & SEd & $C D$ & SEd & $C D$ & SEd & $C D$ & SEd & $C D$ \\
\hline & C & 0.21 & $0.43^{* *}$ & 0.35 & $0.71^{* *}$ & 0.63 & $1.28^{* *}$ & 0.001 & $0.002^{* *}$ \\
\hline & N & 0.21 & $0.43^{* *}$ & 0.35 & $0.71^{* *}$ & 0.63 & $1.28^{* *}$ & 0.001 & $0.002^{*}$ \\
\hline & $\times N$ & 0.36 & $0.74^{* *}$ & 0.60 & $1.22^{\star *}$ & 1.09 & NS & 0.002 & $0.003^{* *}$ \\
\hline
\end{tabular}

$\mathrm{CO}_{2}$ levels $: \mathrm{C}_{\text {amb }}-398 \mu \mathrm{mol} \mathrm{mol}^{-1} \mathrm{CO}_{2} ; \quad \mathrm{C}_{550}-550 \mu \mathrm{mol} \mathrm{mol}^{-1} \mathrm{CO}_{2} ; \mathrm{C}_{2}-750 \mu \mathrm{mol} \mathrm{mol}^{-1} \mathrm{CO}_{2}$

Nitrogen levels : $\mathrm{N}_{0}-0 \mathrm{~kg} \mathrm{~N} \mathrm{ha-1} ; \mathrm{N}_{150}-150 \mathrm{~kg} \mathrm{~N}^{-1} ; \mathrm{N}_{200}-200 \mathrm{~kg} \mathrm{~N} a^{-1} ;{ }^{*} P \leq 0.05,{ }^{* *} P \leq 0.01$, NS - Non significant

therefore the positive correlation of chlorophyll contents in leaves with GS and GOGAT activities can be taken as a support for our interpretation.

The carbon sequestration potential in terms of above ground and below ground biomasses of rice crops exposed to elevated $\mathrm{CO}_{2}$ at varying levels of Nitrogen were assessed. The data demonstrated that elevated $\mathrm{CO}_{2} @ 750 \mu \mathrm{mol} \mathrm{mol}^{-1}$ significantly increased the above ground biomass (straw and grain) by 15.6 and $40.1 \%$, respectively, over the ambient $\mathrm{CO}_{2}$ of $398 \mathrm{umol} \mathrm{mol}^{-1}$. Interestingly, the rice plants under elevated $\mathrm{CO}_{2}$ of $750 \mu \mathrm{mol} \mathrm{mol}{ }^{-1}$ largely increased their below ground biomass (root) by $54.8 \%$ over the ambient $\mathrm{CO}_{2}$ (Table 4 ). In the case of rice plants exposed to elevated $\mathrm{CO}_{2} @ 550 \mu \mathrm{mol} \mathrm{mol}^{-1}$, the above ground (straw and grain) and below ground biomass (root) were significantly increased (9.3 and 24.0, $34.2 \%$ ), respectively over the ambient $\mathrm{CO}_{2}$. These results are in agreement with previous experiments (Kim et al., 2003; Baker, 2004; Krishnan et al., 2007; Madan et al., 2012) and modeling studies (Bannayan et al., 2005) that reported enhanced rice biomass as a result of $\mathrm{CO}_{2}$ enrichment. The increase in aboveground biomass with elevated $\mathrm{CO}_{2}$ is mainly attributed to increased photosynthesis and tiller number (Sakai et al., 2001). Growth during the seedling stage is 'source-limited' and the Carbohydrates increased by $\mathrm{CO}_{2}$ enrichment are efficiently utilized for additional sink such as the development of new tillers or secondary shoots (Makino et al.,1997). Further, the increased below ground biomass is as a result of increased $\mathrm{C}$ allocation to the belowground, changes in root morphology (Kim et al., 2001). In this study, the root/shoot ratio of rice plants under elevated $\mathrm{CO}_{2}\left(750\right.$ and $\left.550 \mu \mathrm{mol} \mathrm{mol}{ }^{-1}\right)$ increased 30.9 and $21.3 \%$, respectively over the ambient $\mathrm{CO}_{2}$. This data is in agreement with Uprety et al. (2000) and Gai-ping et al. (2006) who reported that rice root/shoot ratio was significantly increased by 155 and $35 \%$ under $\mathrm{CO}_{2}$ enrichment in comparison to ambient treatment. The increase in root/shoot ratio may be due to redistribution of carbon in plant tissues since more carbon can be allocated to the roots under elevated $\mathrm{CO}_{2}$ concentrations (Gorissen and Cotrufo, 2000).

In the present investigation, the Nitrogen fertilization was a crucial factor for tapping the carbon sequestration potential of rice plants under higher levels of $\mathrm{CO}_{2}$. Previous studies (Ziska et al., 1996; Seneweera et al., 2005; Kim et al., 2011) have unequivocally demonstrated that the highest Nitrogen doses are pivotal for rice plants to harness the potentials of ' $\mathrm{CO}_{2}$ fertilization effect'. So far the interactive effect of Carbon and Nitrogen on growth has mainly been attributed to two mechanisms. First, inhibition of leaf photosynthesis by Carbohydrate accumulation after prolonged exposure to elevated $\mathrm{CO}_{2}$ tends to be stronger under low than under high nitrogen availability (Rogers et al., 1996). Second, nitrogen uptake increases under elevated $\mathrm{CO}_{2}$ only when nitrogen availability is high (Stitt and Krapp, 1999). Numerous experiments have demonstrated that elevated $\mathrm{CO}_{2}$ greatly increased dry matter accumulation of rice, with the magnitude of the response depending on nitrogen level (Shimono and Bunce, 2009).

Our observations revealed that the elevated levels of $\mathrm{CO}_{2}$ not only enhanced the total biomass of the rice plants but also increased the carbon content of rice roots and straw (Table 5). However, the Carbon content in grains was unaltered. Rice plants exposed to elevated $\mathrm{CO}_{2}$ of 750 and $550 \mathrm{\mu mol} \mathrm{mol}^{-1}$ registered an increase in the Carbon contents of roots ( 8.5 and $2.6 \%$ ) and straw (16.5 and $12.2 \%$ ) over the ambient $\mathrm{CO}_{2}$. These results are in 


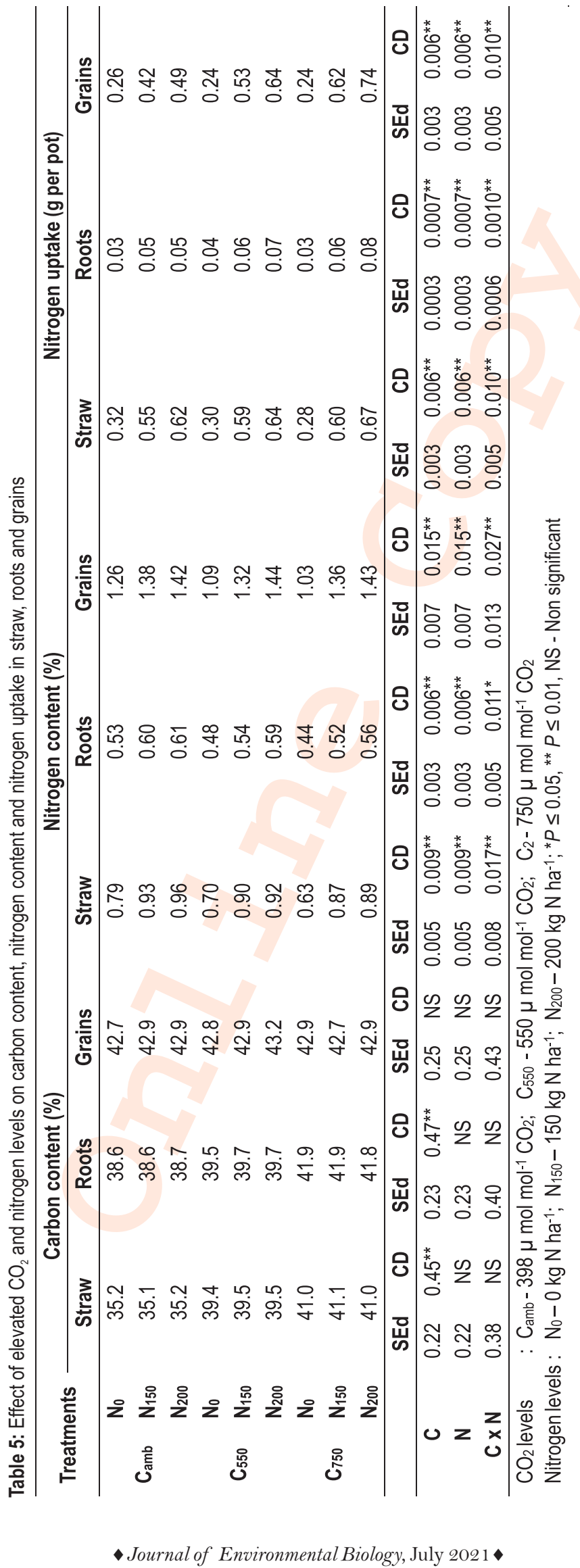


conformity with Uprety et al. (2000) who reported 10 to $15 \%$ increase in the Carbon content of rice leaves, stem and roots exposed to elevated $\mathrm{CO}_{2}$ of 575 to $620 \mu \mathrm{mol} \mathrm{mol}{ }^{-1}$ over the ambient $\mathrm{CO}_{2}$ of $370 \mu \mathrm{mol} \mathrm{mol}{ }^{-1}$. Thus, the combined effect of increased total biomass and Carbon content under elevated levels of $\mathrm{CO}_{2}$ contributed for enhanced plant biomass Carbon stock to the tune of $22.5-34.4 \%, 23.5-45.9 \%$ and $24.5-39.8$ $\%$, respectively through straw, roots and grains over the ambient $\mathrm{CO}_{2}$ (Fig. 3). On the other hand, elevated $\mathrm{CO}_{2}$ significantly reduced the Nitrogen content of rice straw, roots and grains by 5.6 - $10.1 \%, 6.9-12.1 \%$ and $5.2-5.9 \%$, respectively over the current $\mathrm{CO}_{2}$ concentrations. Our results are in accordance with (Weerakoon et al., 2005; Seneweera et al., 2005). This is further supported by Kim et al., (2011) who reported that the elevated $\mathrm{CO}_{2}$ of $622 \mu \mathrm{mol} \mathrm{mol}{ }^{-1}$ reduced the nitrogen content of rice shoot, roots and grains by $15.8 \%, 16.9 \%$ and $21.0 \%$, respectively over the current $\mathrm{CO}_{2}$ concentrations of $398 \mu \mathrm{mol} \mathrm{mol}^{-1}$. It is obvious that these changes in carbon and nitrogen contents led to an increase in the $\mathrm{C}: \mathrm{N}$ ratio of rice plants grown under elevated $\mathrm{CO}_{2}$. The results of this study reveal that under elevated $\mathrm{CO}_{2}$ the $\mathrm{C}: \mathrm{N}$ ratio of rice roots, straw and grains were 82:1, 51:1 and 33.7 whereas the plants under ambient $\mathrm{CO}_{2}$ recorded the $\mathrm{C}: \mathrm{N}$ ratio of $66: 1,39: 1$, and $31: 7$ respectively. These observations are in conformity with the previous reports where (Uprety et al., 2000; Weerakoon et al., 2005; Seneweera et al., 2005; Gai-ping et al., 2006) $\mathrm{CO}_{2}$ enrichment increased rice plant's C:N ratio.

Overall, the results demonstrated that elevated $\mathrm{CO}_{2}$ significantly increased the rice grain yield by $24.0-40.1 \%$ over the current atmospheric $\mathrm{CO}_{2}$ (Fig. 4). Similar findings have been observed by Kimball et al., (2002) and Kim et al., (2011) which reported positive yield responses ( 5 to $71 \%$ ) to elevated $\mathrm{CO}_{2}$ depending upon other factors such as temperature, cultivar and nutrition. Increased grain yield is evident from the fact that elevated $\mathrm{CO}_{2}$ enhanced the accumulation of assimilation and the translocation from source (leaf or stem) to sink (panicle) (Sasaki et al., 2005; Fan et al., 2010). This study clearly demonstrated that the Nitrogen fertilization is a crucial factor for preventing down regulation of photosynthesis and stimulating the grain yield under elevated $\mathrm{CO}_{2}$ levels. Meta-analysis study (Ainsworth, 2008) pointed out that low $\mathrm{N}$ treatments negated any enhancement in rice yield at elevated $\mathrm{CO}_{2}$. Low nitrogen fertilization limited nitrogen uptake during vegetative growth, which constrained any increase in spikelet number, thereby limiting the yield response (Kim et al., 2003). Further, low nitrogen may also cause more pronounced acclimation of photosynthesis to elevated $\mathrm{CO}_{2}$, which can limit total dry matter (Suter et al., 2001; Ainsworth et al., 2003; Razzaque et al., 2011).

Our results demonstrated that Nitrogen fertilization beyond the current recommended dose is pivotal under rising $\mathrm{CO}_{2}$ concentrations for managing the grain quality in terms of Nitrogen concentration. Sasaki et al., (2005); Kim et al., (2011); Wang et al., (2011) who reported that elevated $\mathrm{CO}_{2}$ significantly decreased Nitrogen or Protein concentration in rice grains. This suggests that when adequate nitrogen was not supplied, rice plants grown at high $\mathrm{CO}_{2}$ became inferior to plants grown at ambient $\mathrm{CO}_{2}$ in terms of grain quality. Though our results reported increased nitrogen uptake under elevated $\mathrm{CO}_{2}$, grain nitrogen concentration decreased in the $\mathrm{N}_{0}$ and $\mathrm{N}_{150}$ treatments. On the other hand, the increased grain nitrogen concentration in $\mathrm{N}_{200}$ suggest that the additional amount of nitrogen added might favoured enhanced nitrogen partitioning from source to sink. Our findings are in conformity with Weerakoon et al. (2005) who reported that rice grain nitrogen concentration increased at highest dose of Nitrogen as a result of improved nitrogen partitioning. Thus, $\mathrm{CO}_{2}$ enrichment will favourably improve the productivity and nutritional quality only when the rice plants are nourished with excessive amounts of nitrogen.

\section{Acknowledgments}

The authors gratefully acknowledge the Department of Science \& Technology (DST), Government of India, New Delhi, and the Jawaharlal Nehru Memorial Fund Office for the financial support provided to undertake the study.

\section{Add-on Information}

Authors' contribution: S.K. Rajkishore: Planning and execution of Research work; P. Doraisamy: Mentor; M. Maheswari: Facilitation and guidance for lab experiments; K.S. Subramanian: OTC facility and methodology for nitrogen assimilatory assays; $\mathbf{R}$. Prabhu: Graphical interpretation and editing; G. Vanitha: Statistical analysis.

Research content: The research content is original and has not been published elsewhere.

\section{Ethical approval: NotApplicable}

Conflict of interest: The authors declare that there is no conflict of interest.

\section{Data from other sources: NotApplicable}

Consent to publish: All authors agree to publish the paper in Journal of Environmental Biology.

\section{References}

Ainsworth, E.A., P.A. Davey and G.J. Hymus: Is stimulation of leaf photosynthesis by elevated carbon dioxide concentration maintained in the long term? A test with Lolium perenne grown for 10 years at two nitrogen fertilization levels under free air $\mathrm{CO}_{2}$ enrichment (FACE). Plant Cell Environ., 26, 705-714 (2003).

Ainsworth, E.A.: Rice production in a changing climate: a meta-analysis of responses to elevated carbon dioxide and elevated ozone concentration. Global Change Biol., 14, 1642-1650 (2008).

Anten, N.P.R., T. Hirose, Y. Onoda, T. Kinugasa, H.Y. Kim, M. Okada and K. Kobayashi: Elevated $\mathrm{CO}_{2}$ and nitrogen availability have interactive effects on canopy carbon gain in rice. New Phytol., 161, 459-471 (2003). 
Arora, V.P.S., S.S. Bargali and J.S. Rawat: Climate change: challenges, impacts, and role of biotechnology in mitigation and adaptation. $J$. Prog. Agri., 11, 8-15 (2011).

Baker, J.T.: Yield responses of Southern US rice cultivars to $\mathrm{CO}_{2}$ and temperature. Agr. Forest Meteorol., 122, 129-137 (2004).

Bannayan, M., K. Kobayashi, H.Y. Kim, M. Lieffering, M. Okada and S. Miura: Modeling the interactive effects of atmospheric $\mathrm{CO}_{2}$ and $\mathrm{N}$ on rice growth and yield. Field Crop Res., 93, 237-251 (2005).

Bargali, S.S., S.P. Singh, S.K. Shrivastava and S.S. Kolhe: Forestry plantations on rice bunds: Farmers' perceptions and technology adoption. Int. Rice Res. Notes, 32, 40-41 (2007).

Bargali, S.S., K. Bargali, L. Singh, L. Ghosh and M.L. Lakhera: Acacia nilotica based traditional agroforestry system: effect on paddy crop and management. Curr. Sci., 96, 581-587 (2009).

Bloom, A.J., D.R. Smart, D.T. Nguyen and P.S. Searles: Nitrogen assimilation and growth of wheat under elevated carbon dioxide. Proc. Natl. Acad. Sci., USA, 99, 1730-1735 (2002).

Bruinsma, J.: The quantitative analysis of chlorophylls $a$ and $b$ in plant extracts. Photochem. Photobiol., 2, 241-249 (1963).

Cheng, L. and L.H. Fuchigami: Rubisco activation state decreases with increasing nitrogen content in apple leaves. J. Exp. Bot., 51, 16871694 (2000).

Conroy, J.P.: The influence of elevated atmospheric $\mathrm{CO}_{2}$ concentrations on plant nutrition. Aust. J. Bot., 40, 445-456 (1992).

Cousins, A.B. and A.J. Bloom: Influence of elevated $\mathrm{CO}_{2}$ and nitrogen nutrition on photosynthesis and nitrate photo-assimilation in maize (Zea mays L.). Plant Cell Environ., 26, 1525-1530 (2003).

Epron, D., R. Liozon and M. Mousseau: Effects of elevated $\mathrm{CO}_{2}$ concentration on leaf characteristics and photosynthetic capacity of beech (Fagus sylvatica) during the growing season. Tree Physiol., 16, 425-432 (1996).

Etheridge, D.M., L.P. Steele, R.L. Langenfelds, R.J. Francey, J.M. Barnola and V.I. Morgan: Natural and anthropogenic changes in atmospheric $\mathrm{CO}_{2}$ over the last 1000 years from air in Antarctic ice and firn. J. Geophy. Res., 101(D2), 4115-4128 (1996).

Evans, J.R.: Photosynthesis and nitrogen relationships in leaves of $\mathrm{C}_{3}$ plants. Oecologia, 78, 9-19(1989).

Fan, G., Q. Cai, X. Li, H. Xie and J. Zhu: Yield components and its conformation responded to elevated atmospheric $\mathrm{CO}_{2}$ in three rice (Oryza sativa L.) generations. A. J. Biotech., 9, 2118-2124 (2010).

FAO: Food and Agricultural Organization. Rice Market Monitor, 14, 2 (2011).

Farquhar, G.D., S. Von Caemmerer and J.A. Berry: A biochemical model of photosynthetic $\mathrm{CO}_{2}$ fixation in $\mathrm{C}_{3}$ species. Planta, 149, 178-190 (1980)

Gai-ping, C., C. Lei, Z. Jian-guo, P. Jing, X. Zu-bin and Z. Qing: Effects of free-air $\mathrm{CO}_{2}$ enrichment on root characteristics and $\mathrm{C}: \mathrm{N}$ ratio of rice at the heading stage. Rice Sci., 13, 120-124 (2006).

Geiger, M., P. Walch-Liu, C. Engels, J. Harnecker, E.D. Schulze and F. Ludewig: Enhanced carbon dioxide leads to a modified diurnal rhythm of nitrate reductase activity in older plants, and a large stimulation of nitrate reductase activity and higher levels of amino acids in young tobacco plants. Plant Cell Environ., 21, 253-268 (1998).

Gomez, K.A. and A.A. Gomez: Statistical procedures for agricultural research. John Wiley and Sons, New Delhi, 680p (1984).

Gorissen, A. and M.F. Cotrufo: Decomposition of leaf and root tissue of three perennial grass species grown at two levels of atmospheric $\mathrm{CO}_{2}$ and N supply. Plant Soil, 224, 75-84 (2000).

Humphries, E.C: Mineral components and ash analysis. In: Modern Method of Plant Analysis (Eds.: K. Peach and M.V. Tracey), Springer Verlag, Berlin, pp. 468-502 (1956).
Imai, K., Y. Suzuki, T. Mae and A. Makino: Changes in the synthesis of Rubisco in rice leaves in relation to senescence and N influx. Ann. Botany, 101, 135-144 (2008).

IPCC: Climate Change 2013: The Physical Science Basis. Contribution of Working Group I to the Fifth Assessment Report of the Intergovernmental Panel on Climate Change (Eds. :T.F. Stocker, D. Qin, G.K. Plattner, M. Tignor, S.K. Allen, J. Boschung, A. Nauels, Y. Xia, V. Bex and P.M. Midgley), Cambridge University Press, Cambridge, United Kingdom and New York, NY, USA, p. 1535 (2013).

IPCC: Summary for Policymakers. In: Global Warming of $1.5^{\circ} \mathrm{C}$. An IPCC Special Report on the impacts of global warming of $1.5^{\circ} \mathrm{C}$ above pre-industrial levels and related global greenhouse gas emission pathways, in the context of strengthening the global response to the threat of climate change, sustainable development, and efforts to eradicate poverty (Eds.: V. Masson-Delmotte, P. Zhai, H.O. Pörtner, D. Roberts, J. Skea, P.R. Shukla, A. Pirani, W. MoufoumaOkia, C. Péan, R. Pidcock, S. Connors, J.B.R. Matthews, Y. Chen, X. Zhou, M.I. Gomis, E. Lonnoy, T. Maycock, M. Tignor and T. Waterfield). World Meteorological Organization, Geneva, Switzerland, $32 \mathrm{p}$ (2018).

Jensen, R and G. Bahr: Ribulose, 1,5-bisphosphate carboxylase oxygenase. Ann. Rev. Plant Physiol., 28, 379-400 (1977).

Khatri, K., K. Bargali, B. Negi and S.S. Bargali: Germination and early seedling growth of two rice varieties as affected by invasive Ageratina adenophora. Curr. Agric. Res. J., 8, 108-117 (2020).

Kim, H.R. and Y.H. You: The effects of the elevated $\mathrm{CO}_{2}$ concentration and increased temperature on growth, yield and physiological responses of rice (Oryza sativa L. Cv. Junam). Adv. Biores., 1, 4650 (2010).

Kim, H.Y., M. Lieffering, K. Kobayashi, M. Okadas and S. Miura: Seasonal changes in the effects of elevated $\mathrm{CO}_{2}$ on rice at three levels of nitrogen supply: a free air $\mathrm{CO}_{2}$ enrichment (FACE) experiment. Global Change Biol., 9, 826-837 (2003).

Kim, H.Y., M. Lieffering, S. Miura, K. Kobayashi and M. Okada: Growth and nitrogen uptake of $\mathrm{CO}_{2}$-enriched rice under field conditions. New Phytol., 150, 223-229 (2001).

Kim, H.Y., Sang-Sun Lim, Jin-Hyeob Kwak, Dong-Suk Lee, Sang-Mo Lee, Hee-Myong Ro and Woo-Jung Choi: Dry matter and nitrogen accumulation and partitioning in rice (Oryza sativa L.) exposed to experimental warming with elevated $\mathrm{CO}_{2}$. Plant Soil, 342, 59-71 (2011).

Kimball, B.A., K. Kobayashi and M. Bindi: Responses of agricultural crops to free-air $\mathrm{CO}_{2}$ enrichment. Adv. Agron., 77, 293-368 (2002).

Krishnan, P., D.K. Swain, B.C. Bhaskar, S.K. Nayak and R.N. Dash: Impact of elevated $\mathrm{CO}_{2}$ and temperature on rice yield and methods of adaptation as evaluated by crop simulation studies. Agr. Ecosys. Environ., 122, 233-242 (2007).

Lea, P.J. and B.J Miflin: An alternative route for nitrogen assimilation in higher plants. Nature, 251, 614-616 (1974).

Lewis, C.E., G. Noctor, D. Causton and C.H. Foyer: Regulation of assimilate partitioning in leaves. Aust. J. Plant Physiol., 27, 507$519(2000)$.

Lowry, O.H., N.J. Rosebrough, A.L. Farr and R.J. Randall: Protein measurement with the folin phenol reagent. J. Biol. Chem., 193, 265-275 (1951).

Luo, Y., B. Su, W.S. Currie, J.S. Dukes and A. Finzi: Progressive nitrogen limitation of ecosystem responses to rising atmospheric carbon dioxide. BioSci., 54,731-739 (2004).

Madan, P., S.V.K. Jagadish, P.Q. Craufurd, M. Fitzgerald, T. Lafarge and T.R. Wheeler: Effect of elevated $\mathrm{CO}_{2}$ and high temperature on seed-set and grain quality of rice. J. Exp. Bot., 63, 3843-3852 (2012). 
Makino, A. and T. Mae: Photosynthesis and plant growth at elevated levels of $\mathrm{CO}_{2}$. Plant Cell Physiol., 40, 999-1006 (1999).

Makino, A., M. Harada, T. Sato, H. Nakano and T. Mae: Growth and N allocation in rice plants under $\mathrm{CO}_{2}$ enrichment. Plant Physiol., 115, 199-203 (1997).

Matoh, T., F. Suzuki and S. Ida: Corn leaf glutamate synthase: purification and properties of the enzyme. Plant Cell Physiol., 20, 1329-1340 (1980).

Nakano, H., A. Makino and T. Mae. The effect of elevated partial pressures of $\mathrm{CO}_{2}$ on the relationship between photosynthetic capacity and $n$ content in rice leaves. Plant Physiol., 115, 191-198 (1997).

Natali, S.M., S.A. Sañudo-Wilhelmy and M.T. Lerdau: Effects of elevated carbon dioxide and nitrogen fertilization on nitrate reductase activity in sweetgum and loblolly pine trees in two temperate forests. Plant Soil, 314, 197-210 (2009).

Negi, B., S.S. Bargali, K. Bargali and K. Khatri: Allelopathic interference of Ageratum conyzoides L. against rice varieties. Curr. Agri. Res. J., 8, 69-76 (2020).

Nicholas, J.C., J.E. Harper and R.H. Hageman: Nitrate reductase activity in soybean effect of light and temperature. Plant Physiol., 19, 731$735(1976)$.

NOAA: (2019). https://www.esrl.noaa.gov/gmd/ccgg/trends/global.html

Razzaque, M.A., M.M. Haque, Q.A. Khaliq, A.R.M. Soliman and A. Hamid: Effects of $\mathrm{CO}_{2}$ and nitrogen levels on yield and yield attributes of rice cultivars. Bangladesh J. Agril. Res., 36, 213-221 (2011).

Reich, P.B., Bruce A. Hungate and Yiqi Luo: Carbon-Nitrogen interactions in terrestrial ecosystems in response to rising atmospheric carbon dioxide. Ann. Rev. Ecol. Evol. Syst., 37, 611636 (2006).

Rogers, G.S., P.J. Milham, M, Gillings and J.P. Conroy: Sink strength may be the key to growth and nitrogen responses in $\mathrm{N}$-deficient wheat at elevated $\mathrm{CO}_{2}$. Aust. J. Plant Physiol., 23, 253-264 (1996).

Sadasivam, S. and A. Manickam: Biochemical Methods. New Age International, New Delhi, India, 270p (1991).

Sakai, H., K. Yagi, K. Kobayashi and S. Kawashima: Rice carbon balance under elevated $\mathrm{CO}_{2}$. New Phytol., 150, 241-249 (2001).

Sasaki, H., N. Aoki, H. Sakai, T. Hara, N. Uehara, K. Ishimaru and K. Kobayashi: Effect of $\mathrm{CO}_{2}$ enrichment on the translocation and partitioning of carbon at the early grain-filling stage in rice (Oryza sativa L.). Plant Prod. Sci., 8, 8-15(2005).

Searles, P.S. and A.J. Bloom: Nitrate photo-assimilation in tomato leaves under short-term exposure to elevated carbon dioxide and low oxygen. Plant Cell Environ., 26, 1247-1255 (2003).

Seneweera, S., A. Makino, T. Mae and A.S. Basra: Response of rice to $\mathrm{p}\left(\mathrm{CO}_{2}\right)$ enrichment. J. Crop Improv., 13, 31-53 (2005).

Seneweera, S.P., J.P. Conroy, K. Ishimaru, O. Ghannoum, U. Okada, M. Lieffering, H.Y. Kim and K. Kobayashi: Changes in source-sink relations during development influence photosynthetic acclimation of rice to free air $\mathrm{CO}_{2}$ enrichment (FACE). Functi.
Plant Biol., 29, 945-953 (2002).

Sharkey, T.D.: Photosynthesis in intact leaves of $C_{3}$ plants: Physics, physiology and rate limitations. Botan. Rev., 51, 53-105 (1985).

Shimono, $\mathrm{H}$ and J.A. Bunce: Acclimation of nitrogen uptake capacity of rice to elevated atmospheric $\mathrm{CO}_{2}$ concentration. Ann. Bot., 103, 87-94 (2009).

Stitt, M. and A. Krapp: The interaction between elevated carbon dioxide and nitrogen nutrition: The physiological and molecular background. Plant Cell Environ., 22, 583-621 (1999).

Suter, D., J. No"sberger and A. Lu"scher: Response of perennial ryegrass to free-air $\mathrm{CO}_{2}$ enrichment (FACE) is related to the dynamics of sward structure during re growth. Crop Sci., 41, 810817 (2001).

Suzuki, A. and P. Gadal: Glutamate synthase from rice leaves. Plant Physiol., 69, 848-852 (1982).

Suzuki, Y., A. Makino and T. Mae: Changes in the turnover of Rubisco and levels of $m R N A s$ of rbcL and rbcS in rice leaves from emergence to senescence. Plant Cell Environ., 24, 1353-1360 (2001).

Uprety, D.C., R. Sunitakumari and N.R. Mohan: Effect of elevated $\mathrm{CO}_{2}$ on the growth and yield of rice. Indian J. Plant Physiol., 5, 105-107 (2000).

Vibhuti, C. Shahi, K. Bargali and S.S. Bargali: Assessment of salt stress tolerance in three varieties of rice (Oryza sativa L.). J. Progres. Agri., 6, 50-56 (2015a).

Vibhuti, C. Shahi, K. Bargali and S.S. Bargali: Seed germination and seedling growth parameters of rice (Oryza sativa L.) varieties as affected by salt and water stress. Ind. J. Agric. Sci., 85, 102-108 (2015b).

Wang, Y., M. Frei, Q. Song and L. Yang: The impact of atmospheric $\mathrm{CO}_{2}$ concentration enrichment on rice quality - A research review. Acta Ecologica Sinica, 31, 277-282 (2011).

Weerakoon, W.M.W., K.T. Ingram and D.N. Moss: Atmospheric $\mathrm{CO}_{2}$ concentration effects on $\mathrm{N}$ partitioning and fertilizer $\mathrm{N}$ recovery in field grown rice (Oryza sativa L.) Agr. Ecosyst. Environ., 108, 342349 (2005).

Wullschleger, S.D., R.J. Norby and D.L. Hendrix: Carbon exchange rates, chlorophyll content, and carbohydrate status of two forest tree species exposed to carbon dioxide enrichment. Tree Physiol., 10, 21-31 (1992).

Yaronskaya, E., I. Vershilovskaya, Y. Poers, A.E. Alawady, N. Averina and B. Grimm: Cytokinin effects on tetrapyrrole biosynthesis and photosynthetic activity in barley seedlings. Planta, 224, 700-709 (2006).

Yong, Z.H., G.Y. Chen, D.Y. Zhang, Y. Chen, J. Chen and J.G. Zhu: Is photosynthetic acclimation to free-air $\mathrm{CO}_{2}$ enrichment (FACE) related to a strong competition for the assimilatory power between carbon assimilation and nitrogen assimilation in rice leaf? Photosynthetica, 45, 85-91 (2007).

Ziska, L.H., W. Weerakoon, O.S. Namuco and R. Pamplona: The influence of nitrogen on the elevated $\mathrm{CO}_{2}$ response in field-grown rice. Aust. J. Plant Physiol., 23, 45-52 (1996). 